Mr. Davies Kelvin Udim ${ }^{1}$

Mr. Umar Abubakar ${ }^{2}$

Mr. Joshua Otobong Essien ${ }^{3}$

Department of Educational Foundations

Abubakar Tafawa Balewa University, Bauchi

Nigeria
Original scientific paper

UDC: 371.26

DOI: $10.17810 / 2015.84$

\title{
AN INDEPTH EVALUATION ON THE ISSUE OF EXAMINATION MALPRACTICE IN NIGERIA
}

\begin{abstract}
There is a decline in the quality of graduates from secondary schools in Nigeria. A situation where some secondary school graduates cannot write a very good letter is a cause for concern. Secondary School teachers, parents and the society have always complained about the quality of school products. All these are alarming signals which portends danger for the country. A number of issues could have led to these problems and the most pronounced among them is examination malpractice. Examination malpractice has eaten deep into the Nigeria education system. The purpose of this study therefore was to examine the issue of examination malpractice in Nigeria. The use of secondary sources of data was the main method of data collection adopted in this research work. The secondary sources adopted in this study include materials like Newspapers, magazines, textbooks, internet, journals, government publications, official documents etc. After analyzing the data, it was deduced that collusion among candidates, impersonation, giraffing, inscription, scientific malpractice and bribery were some of the forms of examination malpractice in Nigeria. This study also found that fear of failure, craze for certificates, desire of parents to choose the profession and university, pressure on students to pursue courses which they have no aptitude for were some of the causes of examination malpractice in Nigeria. This study also found that the examination malpractice has a negative effect on the society, leads to irreversible loss of credibility, has negative consequences on the individuals and institutions of learning, leads to moral decadence and brain drain, leads to corruption, it discourages hard work among students. This study also found that measures of curbing examination malpractice include: societal reengineering and re-orientation to revamp moral values, retraining and reassessment of teachers, appropriate recognition and remuneration of teachers and examination officials. Curbing examination malpractice depended on our will power. This study revealed that examination malpractice is not perpetrated by Angels but human beings. Based on the findings above, this study recommended that aggressive campaign should therefore be mounted, educating all the stakeholders about the dangers in engaging in the act and let them be informed of the dignity in having a clean examination system, the Federal Government should try and make the salary of teachers reasonable, qualityand affordable education should be made available for all, this study concluded that Parents should not celebrate success
\end{abstract}

\footnotetext{
1Expensivekel@gmail.com

2Umarbirma6@gmail.com

3 otoobongjoshua2016@yahoo.com
} 
without a commensurate input and that examination malpractice should be discouraged entirely.

Keywords: reasons of malpractice, causes of malpractice, effects of malpractice.

\section{Introduction}

Education is a necessary process through which young adults are equipped to lead productive lives according to their talents and interests (Akaranga and Ongong, 2013). Through education, learners are not only taught, trained, and adequately guided to acquire relevant skills and knowledge but also taught how to adapt to acceptable societal life. To some people, education is seen as a means of overcoming handicaps, achieving greater equality, and acquiring wealth and status for all. Examinations in Nigerian schools dated back to the advent of formal education in the country in the 1800 s and they were modeled after the British system. As such, the 1987 Ordinance made provision for examinations in schools that have attained the requisite percentage of proficiency (Adesina, 1990; Bandele, 2005). Nnam \& Inah (2015) notes that examination is a yardstick against which students or candidates' competence and progress are formally measured and appraised in the education sector. According to Emaikwu (2012), examination as part of evaluation in education is aimed at determining a learner's level of skill acquisition or intellectual competence and understanding after a given training. Evaluation usually enables the teacher to be effectively ready for further teaching as this forms a feedback. George \& Ukpong (2013) opine that examination is the most common tool around which the entire system of education revolves, it is the instrument used to decide who is permitted to move to the next level. Malik \& Shah (1998) cited in Akaranga \& Ongong (2013) observed that examination is not only a process of assessing the progress of students but, it also motivates and helps them to know their academic strengths and weaknesses apart from providing teachers with opportunities to try new methods of teaching. But when examination is not properly conducted, the expected feedback may not be obtained. Hence, the result of such evaluation leads to wrong decisions and judgments which affect the teacher, the learner, the entire education industry, as well as the society (Ojonemi et al., 2013). Whenever there is examination irregularity or malpractice, the validity and resulting outcome is questionable. The common belief on certificates as the only yardstick to measure ones qualification has led many Nigerians to buy educational certificates to prove their academic worth. Examination malpractice in Nigeria is as old as the country itself According to (Anzene, 2014), examination malpractice was first reported in Nigeria in the year 1914, when the question papers of the Senior Cambridge Local Examinations were reportedly seen by candidates before the scheduled date of the examination. The Examination Malpractice Act (1999) explains examination malpractice as any act of omission or commission by a person who in anticipation of, before, during or after any examination fraudulently secures any unfair advantage for himself or any other person in such a manner that contravenes the rules and regulations to the extent of undermining the validity, reliability, authenticity of the examination and ultimately the integrity of the certificates issued. Again, examination malpractice is commonly defined as a deliberate wrong doing contrary to official examination rules designed to place a candidate at an unfair advantage or disadvantage, (Wilayat, 2009 quoted in Akaranga \& Ongong, 2013). Alutu \& Aluede ( 2006) cited in Jimoh (2009) remarked that examination malpractice is any irregular behaviour exhibited by a candidate or anybody charged with the conduct of examination before, during or after the examination that contravenes the rules and regulations governing such examination. Onuka \& 
Amusan (2008) cited in Onuka \& Durowoju (2013) defined examination malpractice as any dishonest or unauthorized action or deed committed by a student on his own or in collaboration with others like fellow students, guardians, parents, teachers, head teacher, examination officials, supervisors, invigilators, security officers and any individual or group of people before, during or after examination in order to obtain undeserved marks or grades. From all the definitions, it is clear that examination malpractice tends to confer undue advantage or undeserved grades to the perpetrators of the act. Again, it may be committed by not only the candidates but also by other bodies charged with the responsibilities of examination management. Undoubtedly, examination malpractice has been a social problem for decades, but the rate and manner it is perpetrated nowadays calls for serious concern. The rate of this crime has become so widespread that there is virtually no examination anywhere at all levels and outside the formal school system that there is no one form of illegal practice or another (Nnam \& Inah, 2015; Ojonemi et al., 2013). Examination malpractices are common everywhere and every examination season witnesses the emergence of new and ingenious ways of cheating, (Nnam \& Inah, 2015; Anzene, 2014; Ojonemi et al., 2013; Jimoh, 2009). It is on the above exposition this term paper will make an attempt to examine the issues of examination malpractice in Nigeria and hopefully reveal the causes and effects of examination malpractice and proffer measures to curb this meance.

\section{Concept of Examination Malpractice}

Olushola (2006) stated that examination malpractice is an unlawful behavior or activity engaged in by students to have personal advantage in an examination over their colleagues or mates who are taking the same examination. Malpractice could be committed before, during or after the examination by either the students taking the examination or by officials assigned with the administration of the examination. Dike (2005) from the psychological point of view saw examination malpractice as all forms of cheating which directly or indirectly falsify the ability of the students. It refers to counter practice that is against the ethics of examination. It is also an act of disrespect to all rules and regulations guiding the good conduct of any examination or any evaluation process.

\section{Examination malpractices could be encouraged as a result of:}

1. Students being sometimes left without any direction or are pushed too hard and too far by parents to achieve the desires of such parents. This problem often makes the candidates to do courses that they cannot cope with, are not interested in, or may not be beneficial to them.

2. Truancy and absenteeism; where students were ill prepared for examination because they do not know what others have been taught. It is natural that when a student does not attend lecture(s), there is no miracle that will make him or her pass, except if he or she indulges in examination malpractice.

3. Lack of proper teaching of students before examination can also encourage examination malpractice. Some school teachers are either lazy or indulged in their private practices when they are supposed to be teaching their students and thus, put in grossly inadequate time in teaching/coaching their students. When the time for examination comes, in order for them to preserve their jobs and also uphold the name of their schools, such teachers tend to resort to examination malpractices.

4. Poor state of infrastructure in schools is another cause of examination malpractice. Where a school lacks such basic facilities such as classrooms, laboratories, libraries and other vital equipment and facilities, teaching and learning cannot be carried out effectively. 
5. Long periods in which schools are closed due to strikes by teachers could also result in examination malpractice. When schools are closed, student are compelled to go back to their various homes and either roam the street, stay idle or engage in nefarious activities. During examination, such students may not be able to recall what they had learnt and the best bet for them is to participate in examination malpractices.

6. Poor admission and promotion policy by schools can also enhance examination malpractice. When admissions are not given to candidates based on merit but based on sentiment, the said students may not be able to withstand the academic stress; the last option for such students will be to embark on examination malpractice. In the same vein, when students are promoted from one class to another without recourse to whether they have passed or not, they tend to be ill equipped at the end of their study and thus depend on examination malpractice.

7. Inadequate staffing of schools is another major reason why students cheat in examinations. For a student to learn and understand any subject matter, he or she ought to be taught adequately. In a situation where students are not taught adequately due to lack of sufficient teachers, such students or schools tend to indulge in examination malpractice to pass examinations.

8. Poor attitude of students towards their studies resulting in non-preparation for examination can also cause examination malpractice. A student, who failed to study hard when he or she has examination to write, will always get involved in examination malpractice in order to pass such examination(s) (Olushola 2006).

\section{Forms of Examination Malpractice}

Onyibe, Uma and Ibina (2015) opine that in every examination, students develop new methods of perpetrating examination malpractices. The instances of examination malpractices vary. They range from impersonation, leakage of questions, tampering with results, and computer fraud to fraudulent practices by invigilators. Some forms of malpractices are discussed below.

1. Collusion among candidates themselves and between them and examination officials: Collusion occurs when candidates writing the same examination copy from one another. When examination official leaks the examination materials to the intended examinees, parents, or overzealous school managers prior to the examination time, the malpractice committed also falls under collusion. Collusion leads to mass cheating in examinations.

2. Impersonation: This is a case where another candidate or hired stand-in sits for examination on behalf of the genuine candidate; Male candidates sitting in for girls or vice versa and twins writing examinations for each other.

3. Giraffing: This form of cheating takes its name from one of the African wild animals with an extremely long neck, legs and small head (Akaranga \& Ongong, 2013). It is a process in which an examinee stretches out his neck as long as possible to view and copy what a fellow candidate has written down for a given question. Giraffing is among the oldest and the commonest form of examination malpractice.

4. Inscription: Students have now advanced to the level of inscribing materials or information on anything like parts of their body for example palms, thighs, baby pampers; handkerchiefs, rulers, purses, chairs, tables, walls of examination halls and so on (Oredein, 2006). Nursing mothers convert the tender skin of their baby to white board; intermittently during examination seek for permission to breastfeed their baby only to use such avenues for note reading or revision. A new examiner will be dumbfounded during NTI Distance Learning and universities part-time programmes' examinations.

5. Irregular activities inside and outside the examination halls: Students, who have made up their minds to cheat, exhibit unwholesome behavior during examination. For instance, 
smuggling out question papers out of the examination hall, sending and receiving information from other candidates or from agents and touts outside the hall, tearing part of the question paper or answer booklet during the examination to perpetrate malpractice.

6. Scientific malpractice/ the use of mobile phones during examinations: Nowadays, candidates employ unauthorized scientific calculators, organizers, compact disc, and mobile phones to take undue advantage. Mobile phones with cameras (imaging functions) are used to take snapshots of a whole textbook in a much reduced format for use during examination. For examination that involves multiple choice questions, candidates inside the examination hall receive the answer through the handsets from their agents even outside that geographical location.

7. Bribery: This form of malpractice may be used to enhance teacher-student collusion to cheat. It brings in the economic perspectives in examination malpractices. A student may pay an examination official some money not necessarily to buy the question paper, but to be allowed to use illegal materials smuggled into the examination halls or to extend the examination scheduled period. In Nigeria, bribery often referred to as sorting in tertiary institutions is rampant. Male students offer money or other valuables while female students use money or sex to bargain for "upgrading" of their examination scores. Bribery is common in both secondary and tertiary levels of education examination.

8. Intimidation / Assault on examination officials: There are reported cases where students and touts brandish dangerous weapons like daggers, pistols, axes, etc. in the examination venues to intimidate invigilators to have a free day while committing the heinous crime. Students who indulge in secret cult activities are more prone to this violent act. The case of intimidation is more evident during external WASSCE / NECO examinations popularly referred to as GCE or during final semester of undergraduate studies examinations.

9. Other forms of examination malpractice include the use of coded sign languages by some candidates, exchange of answer booklets for note comparison or outright impersonation, mass cheating, leakage of question papers, etc.

\section{Causes of Examination Malpractice}

Many reasons have been adduced to be the cause of the prevalent cases of examination malpractice. Petters \& Okon (2013) identifies the causes to include fear of failure, craze for certificates, desire of parents to have their children in choice professions and university, pressure on students to pursue courses which they have no aptitude for, pressure from teachers who want to gain favour of students and overcrowded sitting arrangement. George \& Ukpong (2013) link the increasing rate of examination malpractice to poor teaching, ineffective preparation by students, ill-equipped library facilities, and dubious admission policy. Akaranga \& Ongong (2013) views the cause of examination malpractice to parental upbringing. They opined that because of social status and economic ability, most parents are easily persuaded to bribe their way through for the sole success of their children and selfgratification. According to Ejimogu (2001) cited in Nsisong (2011), general moral decadence and the high premium placed on achievement and certificates by Nigerians has in recent times spawned examination fraud. The overdependence on educational certificates as a measure of one's knowledge and competence has led to a mad rush by most people for educational certificates through unethical means. The disjunction between culturally acclaimed goals and the institutionalized means of achieving these goals coupled with the cultural context of great emphasis on success-goals without equivalent emphasis upon institutional means of attaining these goals have created an environment that predisposes some students, teachers, parents and others to examination malpractice (Jimoh, 2009). The Nigerian society today is 
characterized by a heavy emphasis on success and wealth without a corresponding emphasis on legitimate means and avenues to be used in achieving the success. The country has become a commercial venture and no longer a place for selfless service. The CWO Voice (2010) links examination malpractice to the following factors: rapid growth and demand for education in Nigeria, poor teaching and learning environments, lack of well-equipped teachers who do have the necessary pedagogy to convey the contents to the learners, lack of viable teaching materials/ equipment like standard laboratories, libraries and other things.

\section{Effects of Examination Malpractice}

Onyibe, Uma and Ibina (2015) identify the following as the effect of examination malpractice: 1. In a society where examination malpractice is predominant, its impacts are visibly seen in the type of human resources the education system has produced. Again, educational systems strive to inculcate high level of discipline, diligence, moral love for others; to the recipients where the examination is fraught with malpractice, all the important feedback mechanism become faulted and the educational system becomes distorted (The CWO Voice, 2010).

2. Examination malpractice leads to irreversible loss of credibility. A country that becomes notorious in examination malpractice loses international credibility. The implication is that documents or certificates emanating from such a country would be treated with suspicion as is the case of Nigeria today. Such country's educational institutions are as good as dead as far as international cooperation in education is concerned (Jimoh, 2009).

3. Examination malpractice has grave consequences on the individuals and institutions of learning, communities and the country at large. Dismissal, termination, loss of position, and lack of self-confidence are effects and have caused a lot of embarrassment and suffering to individuals, families and the nation. The guilty ones who were not caught and punished cannot defend the certificates procured not to talk of working at their duty posts.

4. The prevalent rate of bank failures, collapse of buildings, economic sabotage, vandalism, kidnapping/hostage taking for ransom, drug trafficking, fake drug manufacturing and sales are practical effects of moral decadence, emanating from examination malpractice. Effects of examination fraud are displayed in the filling stations, churches, homes, hospitals and markets, practically everywhere.

5. The fight against corruption cannot be realized if examination malpractice continues to be rampant in our educational system. As future leaders who have been equipped through a school system characterized by academic fraud and dishonesty, will certainly manifest this fraudulent behavior in any organization they may find themselves. Those that cheated to pass examination will cheat to get employed, get a spouse, and even to win election through electoral violence or other sharp malpractices.

6. Other effects of examination malpractice include discouragement of students from hard work, low productivity and poor job performances, bribery, corruption, and certificate racketeering. Examination malpractice with its disadvantages is affecting all the facets of the society negatively. The potentials of this nation will be difficult to realize socially, economically, and technologically until the individuals, governments, and other stakeholders in the education sector collaborate to eradicate this malpractice.

\section{Measures of Curbing Examination Malpractice in Nigeria}

No one can claim to have all the solutions to the eradication of examination malpractice in Nigeria, Onyibe, Uma and Ibina (2015) believe strongly that the following suggestions will curtail malpractice to the barest minimum. 
1. Societal re-engineering and re-orientation to revamp moral values: Good moral values should be properly instilled into our youths, and parents counseled to stop aiding their children to cheat in examinations. Again, there is a need to engage only honest persons in examination management. Petters \& Okon (2013) also suggest effective counseling services in schools to assist students acquire techniques of effective study habits.

2. Retraining and reassessment of teachers: Teachers should be equipped for the technologically-driven world (Uzoigwe, n.d). Teachers cannot provide experience and activities that guide students' progress towards understanding of ideas if they themselves do not know what these ideas are; neither can they provide experiences that challenge students if they themselves share in the same misunderstanding (Jimoh, 2009). Since some of the teachers in our various level of education are beneficiaries or products of malpractice, a compulsory nationwide retraining of teachers is very important to re-equip them to impart knowledge. And those found non-trainable should be reassigned with administrative duties.

3. Appropriate recognition and remuneration of teachers / examination officials: Enhanced salary should be paid to teachers and special welfare package given to examination officials to dissuade them from financial and material inducements from students, parents, and others who may want to subvert the examination process. The examination officials include teachers who invigilate examinations, supervisors who oversee the conduct of examinations in schools, officers of examination bodies who monitor the conduct of examinations and law enforcement agents charged with the security of the examination centers.

4. Promulgation and enforcement of examination malpractice (prohibition) laws: The Examination Malpractice Act 33 of 1999 should be amended to re-introduce the parts of Decree 20 of 1984 which advocated for twenty-one (21) years imprisonment for convicted culprits of examination malpractice without option of a fine. If this is fully implemented, it will serve as a deterrent to students, invigilators, security agents, and other collaborators in the malpractice business.

5. Employment of qualified teachers at all levels of education: The need for qualified manpower cannot be overemphasized. The era of agricultural science tutor teaching chemistry, physics, or integrated science under the guise that "science is science" should be over. Trained teachers should be deployed to handle subjects only in their field of specialization. Remember that a medical doctor practicing engineering is a quack.

6. School libraries and laboratories should be adequately equipped: Tools for effective teaching and learning include current and quality textbooks, up to date laboratory equipment, and workshop tools. This vital equipment should be provided and the libraries and laboratories made conducive for learning activities. In fact the whole school environment should be learning-friendly and conducive for human habitation.

7. Proper funding of the education sector: Federal and states annual budgets should be implemented in accordance with UNESCO recommendation of $26 \%$ of states annual budgetary allocation for education. The Nigerian government should realize that education is the bedrock of every society and a springboard for development in a complex and competitive world of today. What we have in our schools today especially in the primary and secondary schools are dilapidated classrooms and classrooms without chairs and tables.

8. Less emphasis on paper qualifications/certificates: Nigeria's education system is largely certificate oriented. Excessive value placed on paper qualification or certificates is the major contributing factor for examination malpractices, that is why candidate would not spare any effort to ensure that they obtained whatever they needed to make a living, whether in a just or unjust way (Onuka \& Durowoju, 2013).

9. The use of effective continuous assessment techniques: Akanni \&Odofin (2015) define continuous assessment (C. A.) as a continuous updating of teachers' judgment about the 
learners' performance in relation to specific criteria which will allow at any time a cumulative judgment to be made about his /her performance. Continuous assessment compels students to make adequate use of their time for studies by completing notes, doing homework, and assignment. On the side of the teachers, it affords an early opportunity to review one's teaching methodology and students' assimilation of the subjects taught. Again, C. A. reduces the anxiety associated with one-shot examinations.

\section{Conclusion}

Since education is the bedrock of every society, any factor or vice that tarnishes the outcome of the learning process must be fought standstill by all stakeholders and well-meaning Nigerians. From the discussion so far, examination malpractice which has remained a cancer in the education sector requires a multidimensional approach for total annihilation. Development of any nation relies solely on its human resources, and human resources are refined to be productive through education, hence eradicating examination malpractice which destroys human resources development should be taken as a full scale war. Restoring that section of Decree 20 from 1984 which stipulated twenty-one years imprisonment on conviction without option of a fine into the 1999 constitution (as amended) will be a right step in the right direction in winning this war.

\section{Recommendations}

Based on the following effects of examination malpractice we recommend the following which could help reduce examination malpractice and make secondary school graduates useful to themselves and to the society.

1. Aggressive campaign should therefore be implemented, educating all the stakeholders about the dangers in engaging in the act and let them be informed of the dignity in having a clean examination system.

2. The government should try and make the salary of teachers reasonable i.e. there should be appropriate recognition and remuneration of teachers.

3. Quality and affordable education should be made available for all.

4. Value and cultural reorientation which is the missing link in the observance of laid down rules and regulations in Nigeria should be emphasized most importantly through the informal education system.

5. Parents should not celebrate success without a commensurate input.

6. Examination malpractice should be discouraged entirely. The government, the citizens, the teachers/trainers, the students/trainees, the family and the school, employers and employees, must take this as a critical assignment that must be done.

7. Schools should endeavor to install electronic signal detectors and telex-electric monitoring system within the examination halls which allow supervisors to watch examination halls with ease.

\section{References}

Adesina, S. (1990). Changing Phenomenon of the Nigeria Educational system, Education and Manpower Vanguard, Thursday, $19^{\text {th }}$ December, 22.

Akanni, O. O., \& Odofin, B. (2015). Reducing Examination Malpractices in Nigerian Schools through Effective Continuous Assessment (C. A.) Techniques as an Alternative to One- 
Shot Examination in Osun State, Nigeria, American Journal of Educational Research, 2(1), 91-101.

Akaranga, S. I., \& Ongong, J. J. (2013). The phenomenon of Examination Malpractice: An Example of Nairobi and Kenyatta Universities, Journal of Education and Practice, 4(18), $87-96$.

Anzene, S. J. (2014). Trends in Examination Malpractice in Nigerian Educational System and its Effectson the Socio-Economic Development of Nigeria, Asian Journal of Humanities and Social Sciences, 2(3), $1-8$.

Bandele, S. O. (2005). Lecturing Examination and Legal Issues in the University System. Paper Presented at the One-day Seminar on Ethics and Accreditation held at the University of Ado-Ekiti, Nigeria on Monday, $16^{\text {th }}$ May 4-6.

Dike, V.E. (2005). Values Education and National Development, Retrieved from: http://www.nigerianvillagesquare.com/content/view/0132/55.retrieved24/4/2008

Emaikwu, S. O. (2012). Assessing the Impact of Examination Malpractices on the Measurement of Ability in Nigeria, International Journal of Social Sciences\& Education, 2(4), 748 - 757.

George, I. N., \& Ukpong, D. E. (2013). Contemporary Social Problems in Nigeria and its Impact on National Development: Implication for Guidance and Counseling Services, Journal of Educational and Social Research, 3(2), 167-173.

Jimoh, B. O. (2009). Examination Malpractice in Secondary Schools in Nigeria: What sustains it?, European Journal of Educational Studies, 1(3): 101- 108.

Nnam, M. U., \& Inah, A. F. (2015). Empirical Investigation into the Causes, Forms and Consequences of Examination Malpractice in Nigerian Institutions of Higher Learning, International Journal of Novel Research in Humanity and Social Sciences, 2(1), $52-62$.

Ojonemi, P. S., Enejoh, W., Enejoh, A., \& Olatunmibi, O. (2013). Examination Malpractice: Challenges to Human Resource Development in Nigeria, International Journal of Capacity Building in Education and Management, 2(1), 91 - 101.

Olushola, A. (2006). Advocates of Examination Malpractice. Retrieved February, 13, 2011 from: http://ezinearticles.com/?Advocates-of-Examination-Malpractice\&id=292923

Onuka, A. O. U., \& Durowoju, E. O. (2013). Stakeholders' Role in Curbing Examination Malpractice in Nigeria, International Journal of Economy, Management and Social Sciences, 2(6), $342-348$.

Onyibe C.O., Uma U.U \& Ibina, E. (2015). Examination Malpractice in Nigeria: Causes and Effects on National Development, Journal of Education and Practice, 6(26), 12-17

Oredein, A. O. (2006). Checking Examination Malpractice in Nigerian Schools. Retrieved from:

Petters, J. S., \& Okon, M. O. (2013). Students' Perception of Causes and Effects of Examination Malpractice in the Nigerian Educational System: The Way Forward for Quality Education. Retrieved from: www.sciencedirect.com/science/article/pii/S187704281305310X

The CWO Voice (06/04/2010). Exam Malpractice: Implication for National Development. Retrieved from http://news2.onlinenigeria.com/news/General/5692-exam-malpracticeimplication-for-national-development.html

The Examination Malpractice Act (1999), Nigeria. www.naere.org.ng/journal/checking_Examination_malpractice_nigerian_schools.pdf

\section{Biographical notes:}

Davies Kelvin Udim was born on January 8th, 1990, in Lagos State Nigeria and did all his primary and secondary school education in same state. He proceeded to akwa lbom State for 
his university education, in the one of the most prestigious department in the school, Department of Educational Foundations, Guidance and Couseling. University of Uyo, Uyo, Akwa Ibom State, Nigeria. Where he obtain his Bachelor of Science in education in political science. He is currently his undergoing postgraduate studies (Masters) in Abubakar Tafawa Balewa University in Educational Administration and planning. He has up to 3 research articles to his name. He is a member of National Association of Educational Administration and Planning (NAEP), Teachers Registration Council of Nigeria (TRCN), National Association of Media and Literacy Education (NAME), Association of Middle Level Education (AMLE),

Umar Abubakar was born in the year 1982, he did all his educational life in the northern Nigeria. He is currently undergoing his postgraduate studies (Masters) in Abubakar Tafawa Balewa University in Educational Administration and planning. He is a member of National Association of Educational Administration and Planning (NAEP). He is married with two kids, he is currently teaching in Government day secondary school, Bauchi (GDSS). And also a lecturer in Sunnah College of Education, Bauchi, Bauchi State(SUNNAH-COE) were he has been lecturing in the department of Educational Administration for more than five years.

Joshua Otobong Essien was born in 1989 in Ikot Obio Odongo Ibesikpo in Ibesikpo Asutan Local Government Area, Akwa Ibom State.Attended ST. Peter's Lutheran Primary School from 1993-1998, he proceeded to Community Secondary Grammar School, Ikot Akpan Ike in Nsit Atai LGA 2000-2006, in 2010 he got his Diploma certificate in Data Processing and Information Technology at IBML Institute of Computers and Business Management. In the year 2015 he bagged his degree certificate in Education and Political science (B.Sc.Ed) in University of Uyo all in Akwa Ibom State.He is currently undergoing his postgraduate studies (Masters) in Abubakar Tafawa Balewa University in Educational Administration and Planning. He is a member of National Association of Educational Administration and Planning (NAEP). He has interest in general reading and music, he is committed to the development of Education in Nigeria and the coast of Africa. 